\title{
Profitability Analysis of Non-Timber Forest Products Marketing in Eastern Hills of Nepal: Looking for an Alternative Marketing Approach to Benefit the Poor
}

\author{
- B.H. Pandit, Ph.D. ${ }^{*}$, R. Subedi** \& C. KUMAR ${ }^{* * *}$
}

\section{SUMMARY}

This paper examines the profitability of selected NTFPs (13 out of 21) traded to India, China, and overseas via Kathmandu, from Eastern Hills of Nepal. The results of this examination reveal that collectors receive much less of a profit margin compared to roadhead and wholesale traders. With the increasing level of processing inputs and trading chains, all of the NTFPs profitability has increased. The profitability has been heavily influenced by collection and transportation costs at the collector's level. While at the roadhead and wholesale traders' level, royalty and processing costs are very important factors to determine profitability. This study reveals that the profit from NTFP marketing has been limited and constrained by several socio-economic and policy-related factors. Specifically, disadvantaged people and women have had limited access to benefits received from NTFP marketing at each level of the marketing chain. There is a fear and uncertainty about how these benefits are equitably distributed among different stakeholders in different marketing chains. Alternative to the existing marketing chain approach, a pro-poor enterprise model has been suggested to benefit the poor.

Key words: Nepal, NTFP trading, profitability, poor people, collectors, traders

\section{INTRODUCTION}

Non-timber forest products (NTFPs) ${ }^{1}$ Non-Timber Forest Products are defined as the diverse array of all useful forest materials including wild plant products, mushrooms, wild honey, wild life products, and aquatic species, other than timber. Cardamom is also included as NTFP as it is also grown on national forests. For the purpose of this study only plant species and their products are included. have the potential to become substantial sources of revenue for rural people in Nepal and abroad (De Beer and McDermott 1996; Arnold and Perez 2001; Pandit and Thapa 2004; Belcher 2005). Increased recognition of the many values of forests has led to new interests and efforts to develop forest products as a means of achieving both development and conservation objectives (Arnold and Perez 2001); Belcher 2005). In areas with marketing facilities, local people are selling raw or processed NTFPs (including handicrafts made from bamboo), to generate the cash income required to fulfil their household needs in Nepal. Each year, Nepal exports about 10,000 to 15,000 tons of NTFPs, comprised of 100 species, to India (Edwards 1996). Annual sales of a single herbal processing company of Nepal during 1999/2000 was worth of 34.8 million Rupees (Herbal Processing Company 2000). From the sale of hand-made paper made from the Daphne bholua (Lokta) species and clothes of Girardiana diversifolia (Allo), Nepal earned a total of four billion rupees in 2002, of which $27 \%$ was exported to USA (Dangal 2002). NTFP sector has contributed almost $9 \%$ of the total forest-based national revenue of Nepal (CBS, 2003).

Many scholars have noted that the Nepal's economy and specifically its traders have benefited considerably from NTFP trading (Edwards 1996; Subedi 1998; Olsen 1998; Pandit and Thapa 2004). What is still unclear is the profitability of NTFPs at each level of marketing chain. Very few scholars have analysed the labour costs for collection and storage and moisture losses of the important NTFPs. We assessed the profitability of 13 NTFPs traded

1 Non-Timber Forest Products are defined as the diverse array of all useful forest materials including wild plant products, mushrooms, wild honey, wild life products, and aquatic species, other than timber. Cardamom is also included as NTFP as it is also grown on national forests. For the purpose of this study only plant species and their products are included.


Nepal, ${ }^{* *}$ Center for International Forestry Research (CIFOR) 
from three hill districts (Sankhuwasaba, Terathum, and Dhankuta) to Kathmandu, India, and Tibet by interviewing 39 collectors/village traders and 20 road-head traders and 44 wholesalers. Besides, we have tried to outline all of the major constraints that affect trade and limit profitability. We hope that the findings of this study will aid in the pursuit of policies and programs conducive to increasing the income of poor families in rural Nepal.

\section{METHODOLOGY}

Data were collected from both primary and secondary sources. Primary data were collected through collectors and traders' survey, group discussions, and observations made by different groups of scientists during varied time periods.

A total of five groups of scientists (NAF, TEF, RRN, New ERA, and LFP) visited different areas of three eastern Hill districts including three custom offices of eastern Nepal and some traders in country's capital (Kathmandu) and regional cities (Biratnagar, Hetuda, and Birgunj) on NTFP marketing. The study teams conducted informal interviews with a total of 39 collectors/ village traders, 20 road-head traders marketing raw-processed NTFPs, 22 processing companies at road-head markets, and 22 wholesale traders. Prior to the interviews, a structured check list for recording data at each level of marketing chain was developed. The data collected at the collector/pity trader level includes collection costs, sale price, moisture loss, cleaning, and transportation costs. At road-head level, sale price, purchase price, storage loss, royalty and taxes, chemical used and labour costs were included. At wholesale level, export duty and value added costs were also included. NTFP market information from Kimathanka area (the northern border of Sankhuwasaba district) was collected by The East Foundation (TEF). The information from the Terai and Kathmandu wholesale traders were obtained by both RRN and NAF. Additional information on some NTFP market prices was obtained from the Livelihood Forestry Program (LFP), the Federation of Community Forestry Users Groups, Nepal, New ERA, the Herbal Production and Processing Centre in Kathmandu, and the Asia Network for Sustainable Agricultural Biodiversity (ANSAB).

\section{NTFP COLLECTION AND MANAGEMENT SYSTEM}

The collection of NTFP from forests (either by communities or government) and private lands is a long established tradition in the eastern hills of Nepal. Data collected in 3 Village Development Committees (VDCs) of SSB district indicates that more than half $(51 \%)$ of NTFPs are collected from government forests, followed by from community forests $(30 \%)$, and then from private lands (19\%). A total of 14 NTFPs (such as Swertia chirayita (chirayita), Lycopodium (Nagbeli), Daphne bholua (Lokta), Edgeworthia gardneri (Argeli), Taxus baccata (Louth salla), Trichosanthes wallichiana (Indreni), Picrorhiza scrophulariflora (Kutki), Nardostachys grandiflora (Jatamansi), Girardiana diversifolia (Allo), Cordyceps sinensis (Yarsagumba), Yajen Bhajuk, Aconitum palpatum (Bikhama), Solanam xanthocarpum (Kantakari, and Aalima) are collected and sold from the upper elevation (above $1500 \mathrm{~m}$ ). Similarly 7 NTFPs (such as Elaeocarpus sphacrius (Rudrakshya), Piper seed (Chabo), Indian madar (Rubia manjith, Trichosanthes wallichiana (Indreni), Cinnamomum tamala (Dalchini), Emblica officinalis (amala) and Asparagus racemosus (Kurilo) are collected and sold from a lower elevation (below $1500 \mathrm{~m}$ ) in the study districts (Table 1).

Taking advantage of the situation of open access, local people harvest NTFPs freely from government forests. Wage laborers hired by the NTFP license holders, mostly from other areas also extract these resources. Local people openly express their frustration regarding such encroachment on the forest by outsiders. However, they cannot prevent outsiders from entering the forest because they lack the necessary legal rights. According to the current forest laws, anybody holding a license issued by the District Forest Officer (DFO) upon payment of the stipulated amount of royalty can extract NTFPs from the government-owned forests in a designated area. Normally, road-head traders have to pay the stipulated royalty to the DFO when they carry NTFPs to capital and regional cities. There is high competition for NTFP collectionamong people in and around the upper elevations because of their attractive benefits. Normally competition is intense for high value NTFPs 
(such as Swertia chirayita, Nardostachys grandiflora, Asparagus racemosus, Daphne Bhoula, and Taxus baccata).

Unlike government forests, access to community forests is limited to the members of the relevant group or community. Unless outsiders resort to poaching, they cannot collect any products from these forests without the permission of the forest's members. Following the adopted rules, timber cutting and firewood harvesting from living trees are strictly regulated by the Community Forest User Groups (CFUGs), and group members rarely dare to transgress the agreed-upon rules. This has resulted in notable improvement in tree density in community forests. This study also confirms the results of the studies conducted elsewhere in the similar ecological condition (Webb and Ambika 2001). Because community forest operational plans do not mention sustainable use and management of NTFP, the degradation of these resources still occurs but less so than compared to government forests. In most cases, the CFUG committees are dominated by the elites, who also conduct trading business in their villages. As a consequence of the village traders' apprehension about losing their income from NTFPs, they (village traders) avoid including a NTFP management plan in the respective forest operational plans.

Collection practices vary from uprooting the whole plant, as in the case of Swertia chirayita, Nardostchys gradiflora, and Asparagus racemosus, to cutting stem and branches of Daphne bhoula, Cinnamomum tamala, and Taxus baccata, cutting runners of Rubia manjith and Tinospora cordifolia, and to scraping lichen from host trees. The collection practices are detrimental to most high-value NTFPs. For instance, Swertia chirayita propagates only from seed, which matures in November and December, but because of food shortages during the rainy season, villagers were uprooting the whole plant during July and August and selling it to road-head traders to obtain money to buy food. The sustainable practice of Picrorhiza scrophulariflora, Asparagus racemosus, and Nardostachys grandiflora collection is to leave two or three roots or rhizomes in the ground when harvesting is done and cover them with soil; however, people were frequently uprooting whole plants without leaving any roots in the ground to regenerate. This practice has resulted in the threat of extinction of these species. Similarly, in the cases of NTFPs such as Taxus baccata, Cinnamomum tamala, and Daphne species, people were felling trees/shrubs indiscriminately without leaving any part of the plants to regenerate in government forests.

\section{NTFP MARKETING SYSTEM}

The marketing of NTFPs in eastern hills mainly takes place from a flow of raw materials in two directions (1) from northern high altitudes to Indian plains (2) from northern High Himals to Tibet/China. However, some of the processed NTFPs such as girardiana clothes, Daphne hand-made paper, and Taxus resin flow to Kathmandu. Girardiana cloth and Daphne handmade paper are sent to Kathmandu by air cargo via Tumlingtar and Taxus resin is sent to Kathmandu via Hetauda. The former two products (clothes and paper) are then exported to other countries such as Japan, Belgium, and Germany.

\section{The marketing channel from northern hill altitudes to Indian cities}

As elsewhere noted (Edwards 1996; Subedi 1998; Olsen 1998; Pandit and Thapa 2004), NTFPs collected by collectors ${ }^{1}$ in villages or collection points are marketed through three-tier channels comprised of petty traders and or collectors in villages, small-scale wholesale traders in the road head market of Basantapur and Hile, and large-scale wholesale traders in Terai and Kathmandu if they are for the use of industries in Nepal. In the eastern Nepal, NTFPs are then exported to India either through Birtamod (Mechi custom office), Biratnagar (Ranibari custom office), and/or Birgunj custom offices.

Due to the small quantities of NTFPs collected, unavailability of transportation facilities, and a lack of awareness about market prices, the majority of local collectors sell NTFPs to Road-head traders. This trade is often facilitated by a verbal contractual agreement under which the collectors receive advance payment in cash and kind during their times of need,

1 Collectors are the petty traders who usually do own land in villages and have connection with road-head traders. They usually hire pro-poor villagers to collect NTFPs and sell NTFPs mostly to road-head traders. Sometimes whole sellers from regional towns have connections with them.

018 
and in turn they are obliged to sell all collected NTFPs to these same traders. The road head traders have well-established contacts with the wholesale traders in Kathmandu, Birgunj, and Hetauda. Therefore, whatever NTFPs they buy from the villagers and local collectors, are sold directly to the wholesalers. Some wholesalers in Kathmandu supply NTFPs to domestic industries, while others export to India and abroad (including Japan and Germany). Wholesalers in Birgunj and Hetauda, however, export all NTFPs to India.

\section{The marketing channel from high hills to Tibet through the Kimathanka border}

A limited trade of NTFPs also flows from high hills of Sankhuwasaba district to Tibet and China via Kimathanka border. A notable example is yarsagumba, the parasitic fungus of a caterpillar found in high altitudes. It is highly valuable through out Asia and in Nepal, itis officially banned as an export in its raw form. There are other 3-4 unidentified NTFPs that flow from Kimathanka border to Tibet. These include yajep bhajuk, bisma, kantakari, and aalima (Table 1). These NTFPs are often traded either by village traders or by wholesalers from Kimathanka, directly to the traders of Dendang and Sigachi villages of Tibet.

\section{NTFP GRADING, STORAGE LOSS, AND VOLUME OF TRADE}

This section briefly presents discussion on the NTFP processing and storage loss followed by volume of NTFPs traded from different market centers and custom offices.

\section{Grading, moisture, and storage losses}

Before NTFPs are sold to traders, unusable parts of all NTFPs are sorted out and, then stored for some time. During cleaning and drying, all NTFPs lose moisture in significant amounts. The moisture loss is highest in case of root NTFPs such as Asparagus (90\%) followed by Daphne bark $(80 \%)$, and Girardiana fibre $(75 \%)$. As soon as the NTFPs are cleaned and dried at collectors' level, they are transported to road-head markets. Therefore, there is small amount of storage loss observed at collectors' level, which has not been included in the analysis. The storage loss on the other hand is largest at road-head traders' level since they have to store NTFPs for longer period of time. The actual duration of storage varies from a day to months, according to the type of the product. For example, asparagus roots, which are prone to damage by fungus if not sold before the onset of monsoon, are generally collected in March to April and sold during September to December. Due to the lack of proper packaging and storage, some losses occur during the storage period. Therefore, the storage losses have been recorded highest (12\%) in Asparagus roots than other NTFPs such as Nardos roots and Swertia (10\% each) and Cinnamon bark (5\%). The amount of loss also depends on the nature and volume of the NTFPs. According to road-head traders, normally bulky NTFPs such as Swertia plants, Taxus baccata leaves, Girardiana, and Daphne fibres have greater losses. The other reasons for such losses are (1) the roadhead traders do not have proper storage facilities preventing NTFPs from direct exposure to sun, rain, and wind, and (2) the unwrapped bundles of NTFPs are stacked on verandas and in thatched huts without walls and dark rooms without ventilation. The damage also occurs at wholesale traders' and final markets. Some processing and even some basic grading and cleaning operations are carried out when products reach their final market in the major cities of India (including Calcutta, Patna, Lucknow, and Delhi).

\section{Quantities of NTFPs traded from different marketing centers of SSB, Terathum, and Dhankuta districts}

Of the 39 important NTFPs collected in the three districts surveyed, only 21 NTFPs were traded in significant amounts from 4 different centers, namely, Kahndbari, Basantapur, Hile, and the Kimathanka border (Table 1).

\section{NTFP traded from Khandbari center}

The data on the volume of trade in different trading centers indicated that chiraito is the dominant product being exported from SSB (Table 1). Of the 21 NTFPs traded from the study districts, only seven NTFPs such as, chiraito, chabo, lokta, allo, jatamansi kudki, and 
cardamom were traded from Khanbari center. Despite a ban on collection and export, people are still collecting and exporting kudki and jatamansi but in small quantities from this center. The record of kutki and jatamansi sales indicated their illegal sale, which was also highlighted in western region of Nepal (Pandit and Thapa 2004).

\section{NTFPs traded from Basantapur center}

Both the volume and number of products (11 NTFPs) traded from different trading channels were compared. Basantapur was found to have the highest volume and number of NTFPs traded compared to the other trading centers (Table 1). The reason for such a high volume of trade in this center was mainly because NTFPs were brought from two or three districts (Terathum, Sankhuwasaba, and Panchthar districts) to this center. With the exception of cardamom, another other three NTFPs (Taxus baccata, Edgeworthia gardneri, and Swertia) were traded in a largest volume from Basantapur center. The NTFP trade record obtained from this center has indicated that Emblica and Terminalia fruits, and Asparagus roots were also traded, but the volume of trade of these products had not been recorded, as the quantity was very small.

TABLE 1. Market arrival quantities of NTFPs in 2002/2003 in five marketing centers

\begin{tabular}{|c|c|c|c|c|c|}
\hline Name of NTFPs & Royalty & NTFP expor & data (in $\mathrm{Kg}$ ) & om different & centers \\
\hline & $\mathrm{Rs} / \mathrm{Kg}$ & $\begin{array}{l}\text { Kahandbari } \\
\text { of SSB }\end{array}$ & $\begin{array}{l}\text { Basantapur } \\
\text { of Terathum }\end{array}$ & $\begin{array}{l}\text { Hile Bazaar } \\
\text { of Dhankuta }\end{array}$ & $\begin{array}{l}\text { Kimathanka } \\
\text { border }\end{array}$ \\
\hline 1. Swertia chirayita (herb) & 3 & 7,500 & 15,400 & 13,200 & 9,240 \\
\hline 2. Elaeocarpus sphacrius & & & & & \\
\hline (Rudrakshya)- fruit & 3 & - & - & 24,000 & - \\
\hline 3. Piper seed (Chabo) & 3 & 350 & 2,100 & 200 & - \\
\hline 4. Lycopodium (Nagbéli) & 5 & - & 280 & 100 & - \\
\hline 5. Daphne bholua (Lokta) & 7 & 8,500 & 7,500 & - & - \\
\hline 6.Edgeworthia gardneri (Argeli) & 3 & - & 75,000 & 2,500 & - \\
\hline 7. Rubia manjith & 2 & - & 10,000 & 2,500 & - \\
\hline 8. Taxus baccata (Louthsalla) & 25 & - & 76,000 & 8,000 & - \\
\hline 9.Picrorhiza scrophulariflora (Kutki) & Banned & 230 & 450 & - & 1,400 \\
\hline 10.Nardostachys grandiflora (Jatamansi) & & 40 & 220 & - & - \\
\hline 11. Girardiana diversifolia (Allo) & 3 & 1,900 & 3,000 & - & - \\
\hline 12. Cordyceps sinensis (Yarsa gumba) & & - & - & - & 2 \\
\hline 13. Trichosanthes wallichiana (Indreni) & & & 3,000 & - & - \\
\hline 14. Yajen Bhaguk & New & - & - & - & 200 \\
\hline 15. Aconitum palpatum (Bikhma) & & - & - & - & 30 \\
\hline 16. Solanam xanthocarpum (Kantakari) & New & - & - & - & 82 \\
\hline 17. Aalima & New & - & - & - & 50 \\
\hline 18. Amomum subulatum (Cardamom) & & 288,000 & 340,000 & 460,000 & - \\
\hline 19. Cinnamomum tamala (Dalchani) & 20 & - & - & 500 & - \\
\hline 20. Emblica officinalis (Amala) & 2 & - & - & 350 & - \\
\hline 21. Asparagus racemosus (Kurilo) & 5 & 100 & 20 & 300 & \\
\hline Total quant & $\mathrm{y} \mathrm{Kg}$ & 306,620 & 529,970 & 511,650 & 11,004 \\
\hline
\end{tabular}

Source: Traders survey, 2004 (data was recorded for the period of January 2003 to December 2003). Total quantity exported from 4 centers $=1,348,240 \mathrm{Kg}$

\section{NTFPs traded from Hile bazaar}

Notably, Hile bazaar has traded a larger quantity of cardamom than the other trading centers. Of the 8 NTFPs traded from Hile bazaar, the sale of Elaeocarpus fruit was a typical example of one which was exported only from this particular center. The other NTFPs sold from Hile Bazaar were Taxus leaves, Rubia runners, Lycopodium powder, and Piper seeds (Table 1).

\section{NTFPs traded from Kimathanka border}

The export of NTFPs from Kimathanka border in the northern belt of SSB has presented an interesting case. Including the Swertia plant, Picrorhiza roots, and Cordyceps, this center had exported another four NTFPs such as yajep bhajuk, bisma, kantakari, and 
aalima. However, the volume of trade of these species was small (Table 1). Since these NTFPs command quite reasonable prices in the Tibetan market, and most of these products are of high value, it is believed that these species have had contributed significantly to the local economy.

\section{NTFP exported from the three Nepal borders to India}

There are no reliable estimates of the demand and supply of NTFPs in Nepal. There can be no doubt that the annual potential harvests might have exceeded the domestic demand. As there are no specific export data for a particular NTFP, the NTFPs are exported in an ad hoc basis. In every Custom Office visited, the Custom Officer at the border was reluctant to provide data on individual NTFPs with the exception of a few products such as Swertia, ginger, pine resin, Elaeocarpus, and cardamom in the Birgunj Custom Office, and Swertia and Elaeocarpus in the Ranibari Custom Office in Biratnagar (Table 2).

TABLE 2: Volume of NTFP export to India and related tax earned in '00 Rs. in 2003

\begin{tabular}{lllllll}
\hline NTFPs & \multicolumn{2}{c}{$\begin{array}{l}\text { Birgunj Custom } \\
\text { Office (Raxaul) }\end{array}$} & \multicolumn{2}{l}{$\begin{array}{l}\text { Ranibari Custom } \\
\text { Office (Biratnagar) }\end{array}$} & \multicolumn{2}{l}{$\begin{array}{l}\text { Mechi Custom } \\
\text { Office } \\
\text { (Kakarbhitta) }\end{array}$} \\
\hline & Qty & Export tax & Qty & Export tax & Qty & Export tax \\
\hline Jadibuti/NTFP & 436424 & 42,000 & - & - & 577,255 & 16,326 \\
Chiraito & 5,250 & 11,000 & 20,160 & 1,178 & - & - \\
Elaeocarpus & 4,307 & 3,000 & 28,040 & 3,000 & - & - \\
Ginger & 229180 & 1,000 & - & - & - & - \\
$\begin{array}{l}\text { Pine Resin } \\
\text { Cardamom sold to }\end{array}$ & 41,563 & 198,000 & - & - & - & - \\
third world countries & 56,720 & 75 & - & - & - & - \\
\hline Total volume & 773444 & 255,075 & 48,200 & 4,178 & 577,255 & 16,326 \\
\hline \multicolumn{3}{c}{ Source: Data recorded in February, 2004. } & \multicolumn{3}{c}{ Total quantity $=1,398,899 \mathrm{Kg}$}
\end{tabular}

A total of 1,398,899 $\mathrm{Kg}$ of NTFPs were exported from three main borders with India in Eastern Nepal (Table 2), which is almost equal to all the NTFPs traded from the three districts (Table 1). Where have the other districts' NTFPs gone? The data clearly indicate that there has been some kind of illegal trading going on in the border area in order to avoid taxes having to be paid to the government. The recent government's tax rules allow traders to export any NTFPs to India without any export duty. Nevertheless, every trader visited by our team complained of paying export duty to the Custom Office for all of the NTFPs they exported to India. Data indicate that the highest revenue was collected at the Birgunj Custom Office. Of the total revenue collected from Birgunj, the highest amount was earned from the export of pine resin (Table 2).

\section{DISCUSSION ON PROFITABILTY OF NTFP MARKETING}

The profitability analysis was done for three groups of NTFPs based on the channel of marketing. These groups include: (1) NTFPs exported in raw/semi-processed form to India via Terai wholesalers; (2) NTFPs exported in raw/semi-processed form to Tibet via Kimathanka border; and (3) NTFPs sold to Kathmandu after processing.

\section{Profit and marketing margins of selected NTFPs traded to India in raw form}

Of the total 11 NTFPs exported to India in raw form, only four NTFPs (Nardos root, Swertia plant, Asparagus root, and cinnamon bark) have been included in the profitability analysis (Table 3 ). The remaining 7 NTFPs were not analysed because these products were marketed at a very low price that even did not even cover the cost of collection. Despite this, farmers have been collecting these species because alternative work has not been available in their villages. 
TABLE 3: Profitability of semi-processed and processed NTFPs (per $\mathrm{Kg}$ ) at collector, road-head, and wholesale trading levels.

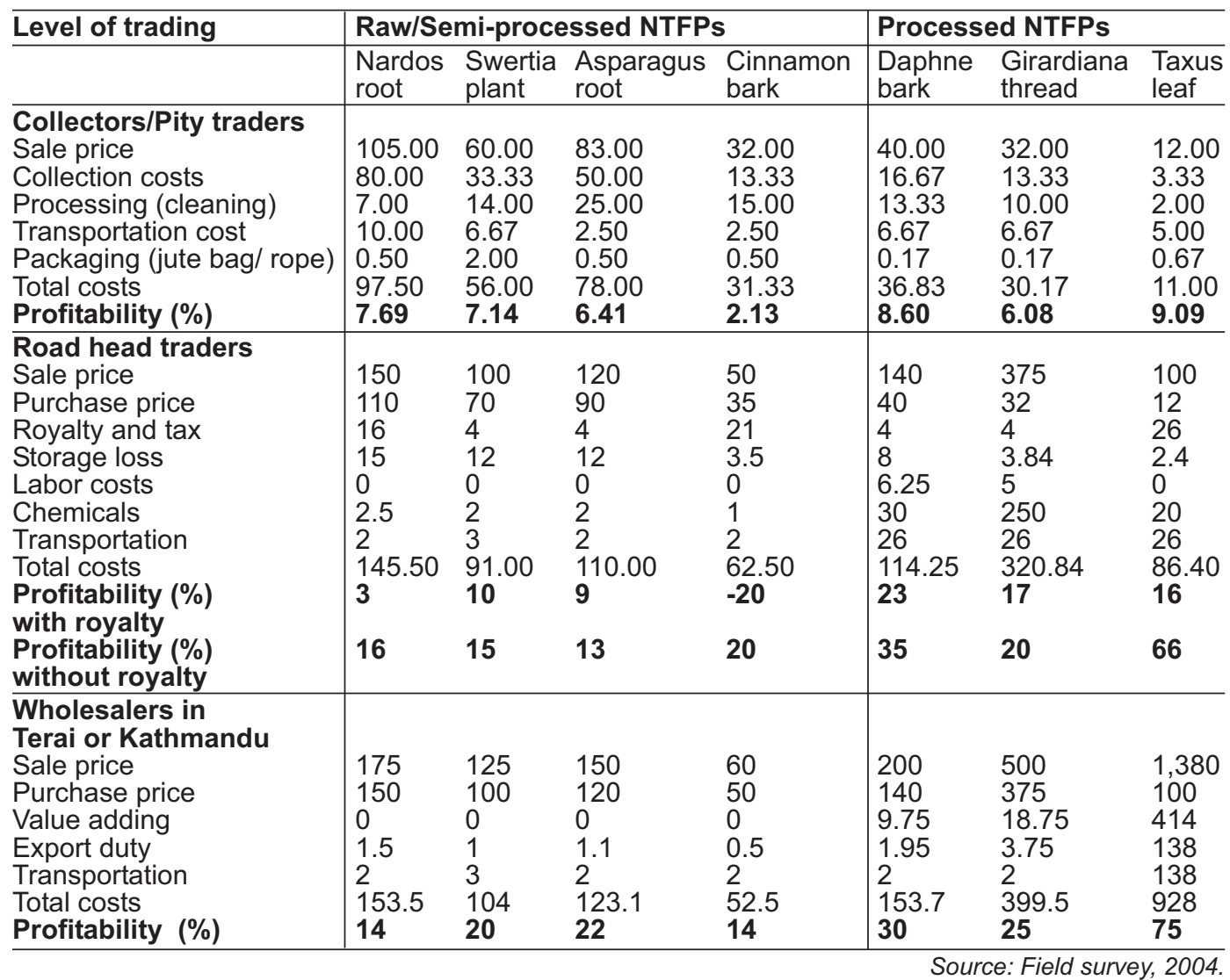

Note:

Profitability $\%=($ Sale price - total costs $) /$ Total costs ${ }^{*} 100$

Collection cost $=$ Daily wage - (no of $\mathrm{Kg}$ of product harvested- moisture loss $\%$ )

Transportation cost $=(\text { Number of days required } / \text { amount of } \mathrm{Kg} \mathrm{load})^{*}$ Daily wage Rs.

The comparison of the profitability of four raw/semi-processed NTFPs shows that a collector receives almost the same percentage of net-return over costs in three NTFPs viz Nardos roots (7.69\%), Swertia plants (7.14\%), and Asparagus roots (6.41\%) (Table 3$)$. The cinnamon bark has the least net-return (2.13\%). The reason for relatively less net-return for Asparagus roots and cinnamon bark was because of high labour costs involved in the processing. On the other hand, the transportation costs are higher in case of Nardos roots as these products were brought from higher hills (above 2,500 m).

The profitability of NTFPs at the road-head trader's level has been heavily influenced by royalty and storage losses. As discussed earlier, of the four NTFPs, Asparagus root has highest storage loss followed by Nardos roots and Swertia plant. Cinnamon bark on the other hand has less storage loss but has highest royalty rate. The existing trend shows that in the absence of an effective premium collection system, road-head traders tend to avoid a substantial amount of such payment (royalty) by selling NTFPs illegally to wholesalers. If a road-head trader pays royalty to the DFO, the profitability of cinnamon bark becomes negative (Table 3). The profitability of the remaining 3 NTFPs (Nardos roots, Swertia plants, and Asparagus roots) is 3,10 , and 9 percent, respectively.

Since the road-head traders are at the gate of each of the districts, the primary producers/collectors have to sell their NTFPs to these traders, who in turn deal with 
Terai/wholesale traders. This layer of marketing channel can be eliminated if collectors are organized into a business organization as proposed by district NTFP strategy of SSB. By doing so, all the profits obtained by these traders could be shared by the collectors/petty traders.

Profit margins of three locally processed NTFPs (Girardiana, Daphne, and Taxus baccata)

Of the total 21 NTFPs traded from three districts (Table 1), two (such as Girardiana and Daphne fibres) generally leave the area in processed form and one (Taxus baccata) is exported in raw form but is processed later in the regional cities of Birgunj and Hetuda before being sent to the Dabar Nepal company in Kathmandu (Table 3). The Dabar Nepal company then sells the resin to the Dabar India company internally at a very high rate. Road-head traders depending upon the situation buy the bark/fibre of Daphne and Girardiana from the collectors/petty traders in different parts of the district. Sometimes collectors may bring the raw Daphne materials (bark) to hand-made paper processing factories. These processing factories then process and makethe paper called Nepali Hate Kagaj, and sell it on to traders in Kathmandu.

Through added value to the Daphne products, the final sales value increases more than triple fold. Meanwhile hile the final sale value of Girardiana cloth increases four folds and Taxus baccata paste/ texol by 8 fold. The profitability analysis indicates that the roadhead traders receive 23, 17 and 16 percent, respectively from Daphne, Girardiana, and Taxus baccata. The profit margin at wholesaler's level of these 3 NTFPs has increased substantially (Table 3 ). Compared to road-head and wholesale traders, the collectors/petty traders have received less of a profit margin. This happens because in each link of the marketing chain, additional value has been added to the products. For instance, in the case of Daphne fibre, the road-head traders made the fibre into paper and at the whole seller's level, these papers were coloured and changed into different forms such as kites, notebooks, calendars etc. This also holds true for the other two products (Girardiana and Taxus). Girardiana fibre is used to prepare various items such as clothes and ropes. These items are generally produced for local use and are very much limited within local markets, thus the economic benefit from their sale are comparatively less at the village level (Bhattarai 2003). When they are sold at road-head and whole sale markets by making them into clothes like coat, shawl, mufflers etc, the profit margin is generally increased. Despite high incentives to process NTFPs nearer the raw material's source, the profit margins obtained by the Girardiana processors at road-head markets are not satisfactory. The profit margin at the road-head is less than the wholesale markets (Table 3 ).

In case of Taxus baccata, the processing companies are developed or supported by the network of Indian traders like the Dabar Company for taxol (cancer medicine) production. Over time, these networks have expanded in many parts of Nepal. Major Indian markets have links with Terain wholesale traders but they have little role in the creation of such industries; their role is confined to satisfying the demand for raw materials. Indian entrepreneurs have therefore been able to maintain strong control over Taxus baccata processing and marketing. This is the reason why its profitability has increased to $75 \%$ from $9 \%$ at the collectors/petty trader's level and $16 \%$ from the road-head traders' level. All these data above indicate that if collectors/petty traders at the village level are supported with adequate equipment and other facilities for establishing processing units for each of the three enterprises, they should increase their profit margins.

\section{Profit and marketing margins of selected NTFPs traded to Tibet/China in raw form}

It was not possible to collect marketing information at collectors' level in the Kimathanka area because of its remote location. Therefore, all costs and benefits of traded NTFPs from Kimathanka border were calculated using information gathered from the road-head traders of the Hatiya and Kimathanka border areas. Villagers reported that road-head traders hired local people as wage labourers to collect NTFPs there. According to road-head traders, six NTFPs (Swertia, Picrorhiza, yajen bhajuk, Aconitum, and aalima) were found to be commonly traded from the Kimathanka border to Tibet/ China (Table 1). 
The profitability analysis indicates that the road-head traders at the Kimathanka border area receive more than two-thirds of the profit margin over costs for four new NTFPs (Yajen Baguk, Aconitum, solanum, and Aalima) (Table 4). Of these four products, Aalima is high value NTFP with selling price Rs. $450 / \mathrm{Kg}$. The profitability of Swertia and Picrorhiza are also higher (24 and 39 percent, respectively). It indicates that selling the Swertia plant to Tibet is more profitable than selling it to India (Table 3 and Table 4). However, increasing transportation costs if exported to India from the northern Himalayan border would incur additional costs. Collection and sale of the Picrorhiza root is banned in Nepal. Despite its ban, traders in the High Himalaya are exporting this product to Tibet without any difficulties. Although the volume of trade is small $(90 \mathrm{Kg})$, the profit margin received by road head traders is $39 \%$ over the costs.

Analysis of the above three NTFPs' market chain systems indicates that when NTFP resources are open to everybody, the access to these resources is inevitably co- opted by powerful agents. The powerless and poor members are always defeated in the game. Many scholars contended that the extractive processes of large scale NTFP commercialization leads to resource exhaustion and price collapse (Pandit and Thapa 2003). Under such circumstances, poor collectors gain almost no benefits.

TABLE 4: Profit margin of NTFPs traded to Tibet

\begin{tabular}{lllllll}
\hline & $\begin{array}{l}\text { Swertia } \\
\text { Plant }\end{array}$ & $\begin{array}{l}\text { Picrorhiza } \\
\text { roots }\end{array}$ & $\begin{array}{c}\text { Yajen } \\
\text { Bhajuk }\end{array}$ & $\begin{array}{l}\text { Aconitum } \\
\text { (Bikhma) }\end{array}$ & $\begin{array}{l}\text { Solanum } \\
\text { (Kantakari) }\end{array}$ & Aalima \\
\hline $\begin{array}{l}\text { Purchase price } \\
\text { (Rs/Kg) at Kimathanka village }\end{array}$ & 140 & 40 & 250 & 150 & 450 \\
$\begin{array}{l}\text { Royalty and tax } \\
\text { (DDC tax Rs. 1/Kg }\end{array}$ & 4 & 9 & 4 & 25 & 15 & 45 \\
\hline Storage loss & 12 & 11.7 & 3.6 & 37.5 & 30 & 76.5 \\
\hline Packaging & 5.00 & 1.67 & 1.25 & 1.67 & 2.5 & 5 \\
\hline $\begin{array}{l}\text { Labor costs for } \\
\text { packaging/handling }\end{array}$ & 2 & 5 & 10 & 8.33 & 50 & 20 \\
\hline $\begin{array}{l}\text { Transportation } \\
\text { (including air cargo of } \\
\text { three processed NTFPs) }\end{array}$ & 2.5 & 2.5 & 3.3 & 2.5 & 2.5 & 3.33 \\
\hline Total costs & 165.5 & 119.87 & 62.18 & 325.00 & 250 & 599.83 \\
\hline $\begin{array}{l}\text { Sale price (Rs/Kg) } \\
\text { in Tibet }\end{array}$ & 180 & 137 & 80 & 550 & 390 & 850 \\
\hline \begin{tabular}{l} 
Profit margin (Rs/Kg) \\
\hline Profitability
\end{tabular} & $\mathbf{4 0}$ & 47 & 40 & 300 & 240 & 400 \\
\hline
\end{tabular}

Source. NTFP survey by TEF, 2004. collectors in the existing marketing chain

Some interesting findings emerge from the analysis of the access of disadvantaged people and women to the existing marketing chain. Their exclusions from chains deprive them of contributions to their socio-economic, cultural, and political lives, which may be gained through participating in the marketing of NTFPs. At the level of village trading, only 2 women and no any disadvantaged members have participated in NTFPs marketing (Table 5).

Table 5: Type of NTFP Traders by Ethnicity and Gender




The participation of indigenous people - GMRLST (who are in the majority in the study districts) - is found to be decreasing with the increasing level of NTFP trade and processing inputs and benefits. The higher caste and wealthier section of society has occupied the whole marketing system. The poor and deprived have had almost no access to the benefits from NTFP marketing. Exclusion therefore works against the norms of civilized order - damaging both individual and society as a whole (UNDP 2004). As in other sectors, this sector also provides a picture of the level of empowerment across the trading chains. It indicates that Nepalese society is deeply rooted in discriminations based on religion, which has also perpetuated both the practice of untouchability and exploitation of women. This can be proved from the fact that more than half of the women and children were found to be engaged in NTFP collection (Pandit and Thapa 2004). When we see their involvement in the trading system, their participation is almost totally neglected. Men and higher caste people have dominated the marketing system.

\section{SOCIO-ECONOMIC AND POLICY RELATED FACTORS HINDERING NTFP MARKETING}

\section{Lack of investment capital leads to constrained profitability by poor people}

The present NTFP marketing system risks marginalizing people who cannot compete elite and wealthy people in the marketplace. The system that does not promote efficiency with an equitable structure of incentives leads to further marginalization of poor. Every time the rich and elite have the chance to invest the capital in the NTFP marketing business.

\section{The outbreak of armed conflict has further squeezed NTFP financial services in} villages

Only a few micro-enterprises that are pro-poor in focus have been working and supporting income-generating activities of the poor in the study districts. In many cases, infrastructure facilities have been disrupted and market information systems have not been available to the people at lowest level of marketing chain.

\section{Double taxation system has discouraged farmers to grow NTFPs in their farms}

The Local Governance Act, 1999 has given enough power to District Development Committees (DDC) in promoting NTFPs-based enterprises in the district. The DDC's role is to identify and develop an industrial area in their respective district. The DDC collects $10 \%$ of the royalties earned from the DFO for any NTFP exported from the district. In addition to this, traders have to pay an export tax to the contractors of the DDC stationed in each check post. Taking advantage of this, traders are charged tax for NTFPs exported from each district. While carrying NTFPs from Sankhuwasaba district to the Indian border, traders have to pay taxes in 5-6 places. Because of this, farmers are discouraged to grow NTFPs in their farmlands. The proof of payment of taxes in one district does not work in another district as explained by various traders and check post officials (DDC/Strategy paper 2003).

\section{Royalty systems are not appropriate for sustainable harvesting of NTFPs}

Of direct relevance to the trade of NTFPs are regulations concerning commerce and taxation. Specific royalty rates for selling NTFPs are specified for particular products in Forest Regulation of 1995. These rates are unclear and sometimes exceed the market price of certain products. For instance, the royalty per $\mathrm{Kg}$ of Cinnamon leaf is 10 Rupees, which is higher than the local market price. We found local collectors selling this product at Rs. 7-8 per Kg at Hile Bazaar. This applies to a lot of other products like the bark of Cinnamomum, lichen plants, and Shorea robusta (sal) leaves. As a result, some NTFPs are illegally traded from SSB district, leaving no records for assessment (SSB strategy paper 2003). Royalty rates, trade regulation mechanisms, enterprise development, and processing provisions are some of the policy-related gaps. 


\section{No clarity in trade name of NTFPs}

The royalty rate of the some of the products mentioned in the Forest Regulation of 1995 differs within species. For instance, the bark of Cinnamomum tamala and root of Rauwolfia serpentina are sold with two trade names to save traders money by avoiding paying taxes (Table 6). Because of this, most of the products are illegally sold without paying any royalty to the DFO.

TABLE 6. Differences in royalty rate of the same NTFP species

\begin{tabular}{llll}
\hline Species & Name mentioned in the & Royalty & Local market \\
& Forest Rule-1995 & Rate (Rs) & Price (Rs) \\
\hline 1. Cinnamomum tamala & Bark of Sinkauli & $100 / \mathrm{Kg}$ & $16 / \mathrm{Kg}$. \\
& Bark of Dalchini & $20 / \mathrm{Kg}$ & $16 / \mathrm{Kg}$ \\
& Tej pat (Cinnamomum leaf) & $10 / \mathrm{Kg}$ & $7 / \mathrm{Kg}$ \\
\hline 2.Rauwolfia serpentina & Chandmoruwa root & $50 / \mathrm{Kg}$ & - \\
& Sarpagandha root & $10 / \mathrm{Kg}$ & - \\
\hline
\end{tabular}

\section{Ban on collection and exports of certain NTFP species encourages illegal sale}

Collection and export bans on certain species are one of the barriers in NTFP trading. For instance, of the 21 NTFPs marketed from the study area (Table 1), only 10 have been mentioned in the records of the forest office (Sankhuwasaba NTFP strategy paper 2003). Local collectors mentioned that there were many other NTFPs such as Sweet flag rhizome (Acorus calamus), roots of jatamansi, bisjara, and kutki, dalchini bark, and fruit of Emblica officinalis and Terminalia chebula were also traded from one of the study districts (Sankhuwasabha). No separate records were made available for other NTFPs. A ban on collection of Picrorhiza roots imposed in 2001 has encouraged illegal sale of this product as confirmed by villagers at Deurali. The Forest Act of 1993 and the Forestry Regulations of 1995 allow the export of processed products to other countries with the good intention of increasing the economic contribution of these products to the local economy through value-adding processing. In some cases, the export of the some NTFPs such as the roots of Nardostachys, leaves of Taxus, and lichen in unprocessed form are not allowed to be exported from one district to another.

\section{Inappropriate permit systems have accelerated NTFP degradation}

Legally, a District Forest Officer can allow outsiders to extract timber as well as NTFPs from government forests adjacent to community forests, as use rights have not yet been formally transferred to the concerned communities. The policy often creates conflict between the local people and district forest officer, such a system discourages the members of community forests from conserving NTFP resources. Anybody can get an NTFP collection permit from the DFO in government forest. Sometimes more than one person is allowed to collect NTFPs in one patch of the forest, leading to serious competition by permit holders. Such a system has accelerated the pace of NTFP degradation, as reported by one of the collectors.

\section{Weak backward linkages}

Because of weak backward linkages, as well as creation of a few NTFP processing companies at road-head and wholesale markets, the benefits received by this sector is extremely uneven - and indeed, limited largely to urban business companies. The profit margin of NTFPs at the petty traders' level is limited and risks making the business unsustainable. 


\section{CONCLUSIONS AND RECOMMENDATIONS}

\section{Promote group marketing with poor people's shareholdings}

To make NTFP trading a financially viable activity, particularly for the collectors (poorest of the poor households), it is essential to organize all the groups of people who are involved in NTFP collection and selling locally. In order to enable them to sell products directly to the wholesale traders in the cities of Kathmandu and in Terai (Birtamod, Biratnagar, and Birgunj), a net work of all NTFP stakeholders has to be formed at least at the subdistrict level from where they can control the illegal trading (NTFP Strategy paper 2003). By doing so, the role of road-head traders who are the bottleneck of NTFP trade could also be minimized. The poor collectors on the other hand, would receive benefits in four ways: (1) by being members of the local groups e.g. CFUG; (2) by productivity bonus; (3) by employment in the processing company; and (4) by share dividends. The establishment of such business organizations at the local level has already been put into place in SSB district.

\section{Provision of market information and micro credit program}

In view of the weaknesses and the difficulties that the collectors and the village traders face, we cannot expect that the collectors and village traders sell NTFPs directly either to wholesalers (in Terai and Kathmandu) or to Indian traders. The proposed restructuring of the marketing system would require the provision of an excellent market price information collection and dissemination system simultaneously with the promotion of a group marketing system and the provision of a micro-credit program, enabling the network members to borrow small amounts of credit in time of need.

\section{Improving indigenous technology with the provision of village based training}

Since local collectors and village traders are not allowed to export some of the NTFPs in raw form, they need to be taught additional skills for processing these products. Additional benefits will be acquired by improving indigenous processing and storage technologies. This demands the provision of village-based training programs. Provision of training on sustainable NTFP collection and management practices also has to be made for the villagers. Without these institutional reforms and sustainable collection practices, villagers will lose the opportunity to earn some cash income, as the stock of NTFP is gradually dwindling in forests.

Develop participatory monitoring mechanisms for policy-making people with the local level stakeholders and local pressure groups

In order to make NTFPs a perennial source of income for poor people, it is necessary to end the open access status of government forests by a participatory monitoring of the DFO and other stakeholders, which needs to assess the carrying capacity of governmentmanaged forests. Legal issues hindering the efficient functioning of the NTFP marketing system and sustainable utilization of NTFP resources highlighted earlier need to be resolved by putting pressure on policy-making people. The recent NTFP policy document has, however, tried to resolve some of the issues but many of them still remain unsolved.

\section{REFERENCES}

ARNOLD, J.E.M. and PEREZ, M.R. 1998. 'The role of non-timber forest products in conservation and development', In WOLLENBERG, E. and INGLES A., Incomes from the Forest: Methods for the development and conservation of forest products for local communities. Centre for International Forestry Research and The World Conservation Union.

BELCHER, B. 2005. 'Production to consumption systems: An approach to understanding NTFPs in rural economies and forest conservation'. Paper presented at an International symposium entitled, "A Future Beneath the Trees" held at Royal Roads University, Victoria, British Columbia, Victoria, Canada on August 25 to 27. 
BHATTARAI, T.P. 2003. Study of Non-Timber Forest Product Marketing in Sankhuwasabha District. RRN report submitted to Arun Valley Sustainable Resources Use and Management Pilot Demonstration Project (AVASRUM PDP), Lazimpat, Kathmandu.

BHATT I.D., RAWAL, R.S. and DHAR, U. 2000. 'The availability, Fruit Yield and Harvest of Myrica esculenta in Kumaun (West Himalayan), India'. Mountain Research and Development 20 (5): 46-153.

DANGOL, B.D. 2003. 'Problems in operation and export of Nepali Hand Made paper and paper products', Page 19 -26. Quarterly Report of the Nepal Hand Made Paper Association, Kathmandu.

DDC/NTFP STRATEGY PAPER, 2003. 'Non-Timber Forest Products (NTFPs) strategy and program of Sankhuwasabha district endorsed by the District Development Committee'.

DE BEER, J.H.D, MCDERMOTT, M.J. (1996). The economic value of NTFPs in South East Asia. The World Conservation Union (IUCN).

DEN HETROG W.H. and WIERSUM, K. F. (2000). 'Timur (Zanthoxylum armatum) production in Nepal, dynamics in non- timber forest resource management'. Mountain Research and Development 20 (2): 36-145.

EDWARDS, D. M., 1996. 'The trade in non-timber forest products from Nepal'. Mountain Research and Development 16 (4), 383-394.

OLSEN, C.S., 1998. 'The trade in medicinal and aromatic plants from central Nepal to Northern India'. Economic Botany 52(3) pp. 279-292.

OLSEN, C.S., and HELLES, F., 1997. 'Medicinal plants, markets and margins in the Nepal Himalayas: Trouble in paradise'. Mountain Research and Development 17: 363-374.

SIDHU, D.S., 1997. Measures to enhance the efficiency of agricultural marketing systems: Case of India. Marketing Systems for Agricultural Products, A Seminar Report, Asian Productivity Organization, Tokyo. 104-132 pp.

PANDIT, B.H. and THAPA, G.B. 2004. 'Poverty and resource degradation in the mountains of Nepal'. Society and Natural Resources, 17:1-16.

PANDIT, B.H. and THAPA, G.B. 2003. 'A tragedy of non-timber forest resources in the mountain commons of Nepal', Environment Conservation, 30 (3) 283-292.

UNDP, 2004. Nepal Human Development Report- Empowerment and Poverty Reduction. United Nations Development Programmes, P.O. Box 107, Pulchok, Kathmandu, Nepal.

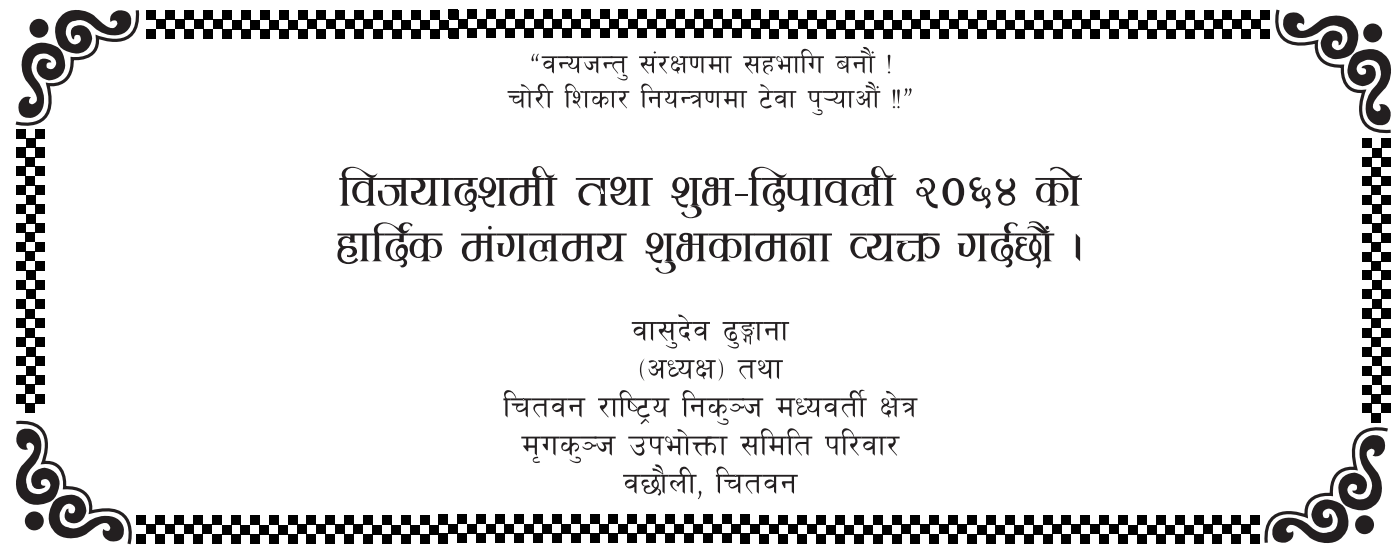

028

The Initiation 2007 